\title{
A Vignette Study of Middle Managers' Responses to Continuous Improvement Initiatives by Top Management
}

\author{
Freek Hermkens
}

Sharon Dolmans

\author{
A. Georges L. Romme \\ Eindhoven University of Technology \\ Department of Industrial Engineering \& Innovation Sciences \\ Netherlands
}

\begin{abstract}
To better understand why continuous improvement (CI) initiatives often fail and do not result in sustained changes, this paper investigates how management's conceptualization of a continuous improvement program affects its implementation via middle managers. The study serves to identify the differences in outcomes of CI initiatives arising from implementing CI as an integral management versus an efficiency-improvement approach. This research draws on a vignette study (i.e. scenario experiment) with 107 middle managers working at one of the largest financial institutions in the Netherlands. The findings arising from this study suggest that CI is more likely to be adopted into the organizational culture, enhance the customer orientation among employees and improve the work atmosphere, when it is implemented as an integral management approach rather than as an efficiency-oriented program.
\end{abstract}

Keywords: Continuous improvement, lean, middle management, organizational change, customer orientation, vignette study, financial institution

\section{Introduction}

Changes within and around organizations are the order of the day (By 2005), for example, those arising from the need to (often simultaneously) reduce cost, improve quality, decrease time-to-market lead times, and enhance flexibility (Lasrado 2018; Oakland and Tanner 2007; Shafiq et al. 2019). In addition, financial service providers increasingly have to deal with a growing amount of legislation and regulations. This creates additional pressure on the existing resources and an increasing need to deploy them efficiently (Banerjee and Mio 2017; Hancock and Dewatripont 2018). In many organizations, top management seeks to address these major challenges by initiating changes toward Continuous Improvement (CI) - an organizational culture in which all members contribute to performance improvement by continuously implementing minor or major changes in their work processes (Hellsten and Klefsjo 2000; Holmemo and Ingvaldsen 2016).

However, achieving a sustained organizational practice of CI proves to be rather difficult (Glover et al. 2015; McLean et al. 2017; Pearce and Pons 2017). In this respect, creating a CI culture that is sustained over many years requires the commitment, involvement and leadership of the entire management of the organization (Dahlgaard and Dahlgaard-Park 2006; Snee 2010). While top management is responsible for initiating and stimulating a cultural change to support the CI principles throughout the organization (Al-Najem et al. 2012; Mann 2009), middle management has a highly critical role in implementing CI throughout the organization, by acting "as a cornerstone between top management and bottom line workers" (Al-Najem 2012, p. 119). Middle managers' position and knowledge about what motivates the employees in their unit or department allows them to increase the likelihood of realizing change (Buick et al. 2018; Engle et al. 2017; Floyd and Wooldridge 1992; Huy 2011), in particular by facilitating sustained changes (Fine et al. 2008) that is making middle managers key agents in renewal efforts such as implementing a CI strategy (Collis 2016; Floyd and Lane 2000; Jayaram et al. 2008; Rahman et al. 2010).

Although CI programs are typically initiated by referring to 'sustained improvement' and similar terms, they often end up as a quick fix for problems without a deliberate effort to create and maintain the conditions needed (Bhuiyan et al. 2006; Snee 2010).Top management may initially pursue CI as a long-term integral management approach, but may frame targets so as to establish short-term cost-cutting results (cf. McCannet al.2015). Indeed, in practice, there is often a discrepancy between what top managers say they want and what they actually want (e.g. Argyris 2004; McCann et al. 2015; Van Maanen and Barley 1984). 
This gap between the purpose and values of CI espoused by top management and those actually being pursued may then result in an almost conflicting organizational reality. In this context, middle managers are facing rather challenging conditions when their top management sets out to develop a culture of CI. These conditions include the ambiguity around the broader aim of the CI program and what top management expects from them. To better understand why CI initiatives often fail to result in a sustained cultural change, this paper seeks to understand how top management's conceptualization of a CI initiative affects the way middle managers perceive and act upon the Figure 2.1 Research model

initiative. To examine the effect of different ways of conceptualizing a CI initiative within the organization, this study draws on a random experiment with 107 middle managers of a large bank in the Netherlands. As part of this study, the managers evaluated a vignette: a description of the implementation of a CI project within the bank, with some deliberate manipulations. Half of the managers received a vignette describing a CI initiative to be implemented as an integral management approach and the other half received a vignette of a CI initiative to be implemented as an efficiency program. The experiment reveals that when CI is implemented as an efficiency program it is less likely to be adopted into the organizational culture, whereas implementation of CI as an integral management approach is more likely to result in a customer-focused culture with a better work atmosphere. The remainder of this chapter is structured as follows. First, this paper describes the theoretical background of this study. The subsequent section covers the experimental research design, followed by the results. Finally, the main findings are discussed and conclusions are drawn.

\section{Theoretical Background}

A large number of studies on CI have focused on the sustainability of its implementation (Bhuiyan et al.2006), including critical success factors (Achanga et al. 2006; Sim and Rogers 2009), pitfalls (Chen et al. 2010; Gurumurthy and Kodali 2011), culture (Angelis et al. 2011; Bhasin and Burcher 2006) and lean leadership (Mann 2009; O'Rourke 2005).Top management appears to have an important role in the successful implementation of CI (Jørgensen et al. 2003; Kay and Anderson 1999).In this respect, top management is responsible for creating a change-oriented culture and adopting new organization-wide ways of working. Hence, top management should stimulate a cultural change to support the implementation of CI principles throughout the organization (Mann 2009; Snee 2010). Yet, when top management (perhaps unintendedly) generates ambiguity around the broader aim of the CI program, for example by setting short-term efficiency targets, the implementation of the CI program may fail to reach its intended (sustainable) cultural change. In particular, middle managers may interpret the initiative as a cost-cutting exercise, undermining the necessary cultural change. The remainder of this section serves to develop three hypotheses about how framing by top management may influence the way in which middle management acts upon CI initiatives. These hypotheses address three key dimensions that reflect how middle managers perceive and act upon CI initiatives, namely organizational culture, customer focus and work atmosphere. This paper focuses particularly on these dimensions, because this are vital and critical aspects for implementation of CI programs (e.g. Achanga et al. 2006; Angelis et al. 2011; Cudney and Elrod, 2011).

\subsection{Organizational Culture}

Managers in many organizations are increasingly aware of the fact that the introduction of CI is not a quick fix. In this respect, CI practices such as Lean have recently become more mature and professional in nature (Aloini et al. 2011; Hines et al. 2018; Rother 2010). While CI's initial focus was on improving efficiency, CI methods have evolved towards an emphasis on changing the organizational culture (Basu and Ahmed 2012; Heine et al. 2016).CI programs such as Lean are about reducing waste and non-value adding activities in the entire organization but also about changing the corporate culture (Bhasin and Burcher 2006; Chen et al. 2010). The cultural change is typically one of the biggest challenges in implementing CI (Bessant et al. 1994; Lacksonen et al. 2010). We consider the organization culture to be CI oriented when (a) all managers act as role models in continuous improvement by demonstrating commitment as well as by creating a sense of urgency about doing things differently, and (b) everyone in the organization is intrinsically committed to reducing waste and improving quality in the entire organization. As Dahlgaard and Dahlgaard-Park (2006) stated, creating such a culture is not a quick fix. To create a CI culture, commitment of workers is essential (Angelis et al. 2011; Kay and Anderson 1999).

It is therefore important that CI is conceptualized as an integral management approach (Bhasin and Burcher 2006), thereby ensuring top management's structural commitment towards CI as an integral part of the way the organization is organized and managed. This top management commitment can be regarded as conditional for creating a cultural commitment towards CI among workers (Angelis et al. 2011; Bessant et al. 2001). In addition, top management is responsible for creating a change-oriented culture and adopting new organization-wide ways of working. Hence, top 
management should stimulate a change in mind set and behaviour to support middle management in getting CI principles adopted throughout the organization (e.g. Mann 2009; Snee 2010).

However, cultural and behavioural changes at the managerial level are often difficult to accomplish, because there is a strong tendency among (both top and middle) managers to focus on tools and techniques and there is too little focus on knowledge transfer (Hines and Butterworth 2019; O'Rourke 2005; Zarbo 2012). Most organizations do, however, not (sufficiently) consider the people component in change (Hines and Butterworth 2019). As such, their focus is mainly on process (efficiency) improvements (Ramakrishnan et al. 2009). This makes it hard to sustain the improvements, once they are implemented (McLean et al. 2017; Rentes et al. 2009).

In this respect, Bhasin and Burcher (2006) observed that successful implementation involves viewing CI practices as a long-term journey and making cultural changes (as deemed necessary) to support these practices throughout the entire organization. As such, top management needs to promote a culture of CI by demonstrating management commitment as well as by creating a sense of urgency about doing things differently (Al-Najem et al. 2012; Boyle et al. 2011; Snee 2010), which serves to create the conditions for middle management to engage in quality and process improvements in an early stage and embed the latter in the organization's operations (Balding 2005; Davis and Fisher 2002). An empirical study by Mann (2005) suggests that the success rate of CI implementation efforts is for about 80 percent determined by cultural factors, and the remaining 20 percent involves the tools and processes of CI themselves. Overall, one of the biggest challenges in implementing CI is the required cultural change. This cultural change is more likely to come about when top management adopts a long-term integral approach, rather than a short-term focus (e.g. on implementing a tool). Moreover, commitment of workers appears to be essential for creating a CI culture, and middle management evidently plays a pivotal role in creating and sustaining this commitment. This leads to the following hypothesis: H1: When CI is implemented as an integral management approach rather than an efficiency improvement program, it is more likely that middle managers perceive CI to become better integrated in the organizational culture.

\subsection{Customer Focus}

Focus on the customer is essential to any business (Bodine 2011; Madhani 2017; McGinn 2011). This customer focus can be obtained by CI practices such as Lean, which have a strong focus on customers and eliminating waste (AndrésLópez et al. 2015; Hines et al. 2011; Womack and Jones 2005).CI programs can help to analyse and identify customer needs (Hirzel et al. 2017). Nowadays, customers are demanding products and services of high quality and with top service delivery and low prices, while at the same time demanding that organizations constantly surpass their customers' expectations (Azuan and Ahmad 2013; Bicheno 2008).As a result, many companies need to develop a sense of urgency about customer focus among their workers and managers (Gulati and Oldroyd 2005; Parasuraman et al. 1991; Vandermerwe 2004). Standardizing services and increasing reliability in service through optimized processes can improve efficiency and increase competitiveness (Carlborg et al. 2013; Van Dun and Wilderom 2016). By using Lean and other CI methods, organizations learn to focus on aspects such as creating customer value and improving customer satisfaction (Aarnio 2015; Bhamu and Singh Sangwan 2014; Womack and Jones 2005).

Besides the focus on customers, the pursuit of efficiency is an important point for all businesses (Van Dun and Wilderom 2016), including financial institutions (Duncan and Elliott 2004). At the same time, there are also studies that show an increase in efficiency in services often implies a decreasing customer satisfaction and, in turn, lower levels of financial performance (Anderson et al. 1997; Duncan and Elliott 2004). This is in line with the widespread usage of Lean-oriented CI programs that strongly emphasize internal flow efficiency, which in turn may negatively affect customer satisfaction (Carlborg et al. 2013). Also, previous research shows that if there is a conflict between cost efficiency and customer satisfaction, top managers tend to prefer cutting cost (Parasuraman 2002). The pressure to cut costs as well as sustain or grow a unit's performance (e.g. productivity or customer satisfaction) may undermine middle managers' efforts and commitment to implement CI (Sim and Rogers 2009; Stoker 2006). However, the service industry can benefit from the implementation of CI programs such as Lean by increasing organizational competitiveness and customer satisfaction and reducing process variability and waste (Andrés-López et al. 2015). As such, many organizations have been exploring ways to improve their business, for example by providing better services against lower cost levels and improving customer satisfaction (Bhuiyan et al. 2006; Snee 2010). The role of middle management in Lean and other CI practices arises from what top management aims to accomplish (Bhasin 2011; Bhasin and Burcher 2006). Lean programs intended to cut costs often end up as a quick fix with a lack of customer focus (Bhasin 2011, 2012; Bhuiyan et al. 2006).By contrast, organizations embracing Lean as an integral approach toward CI tend to perform better (Bhasin 2011). In sum, this gives the following hypothesis: H2: When CI is implemented as an integral management approach rather than an efficiency-improvement program, middle managers expect people in the organization to become more focused on customers. 


\subsection{Work Atmosphere}

Implementing CI may provide opportunities to workers in the organization to participate in improvement programs and enhance their job scope (Angelis et al. 2011). When a CI program is implemented, itis essential to take care of (balancing) the wellbeing of employees as well as the performance of the entire organization (Basu et al. 2015). Middle management has to feel supported and a long-term horizon needs to be adopted (Heine et al. 2016; Netland 2016). In this respect, when implementing CI, middle managers need to be empowered to act (Nelson and Yeo 2012; Song et al. 2014).

When top managers seek to implement $\mathrm{CI}$ as an integral management approach, middle managers may feel more secure, enabling them to better coach and support their staff (McQuade 2008) and facilitate knowledge transfer about CI (Caughron and Mumford 2011; Vänje and Brännmark 2017). As such, middle managers can increase the skills and knowledge of the entire workforce and stimulate workers to develop themselves (Lam et al. 2015; Poksinska et al. 2013; Van Assen 2018). In other words, middle managers can adopt a learning mindset and stimulate employee participation (Buick et al. 2018; Delizonna 2017; Vänje and Brännmark 2017). However, when CI is implemented as an efficiency improvement program, several studies have observed that organizations may go too far in their optimization efforts, for example by eliminating all the available human potential, resulting in an organization-wide aversion of CI methods (Chen et al. 2010; Sim et al. 2015). While systematic waste elimination may improve performance, it also increases the work load and the intensity of work (Angelis et al. 2011; Basu et al. 2015). This can, in turn, result in managers feeling extremely stressed as well as in lower levels of productivity (Cascio 1993; Harrington and Williams 2004).

In this respect, middle managers have been observed to actively block empowerment, in attempts to preserve the power and status they felt was being reduced or lost (Denham et al. 1997). Empowerment of employees may cause anxiety among middle managers when they can no longer control decisions made at lower levels and when formal communication channels are being rearranged. As such, the increased level of responsibility and autonomy to act among the 'subordinate' staff may make middle managers feel increasingly exposed to, and threatened by, a so-called 'parallel hierarchy' (Holden and Roberts 2004; Psychogios et al. 2009). Moreover, top managers evidently appear to have an important role in empowering and supporting their middle managers in ways that enhance confidence and efficacy in fulfilling their new role (Song et al. 2014; Tippman et al. 2013). When top management implements CI as an integral approach, it can be expected that middle managers are more likely to focus on developing their skills and knowledge (to transform themselves) as well as those of their subordinates, as opposed to implementing CI as an efficiency program, where the focus may be too much on downsizing, resulting in lower employee morale. These arguments lead to the third hypothesis: H3: When CI is implemented as an integral management approach rather than an efficiency-improvement program, middle managers expect that the work atmosphere becomes better.

\section{Method}

To investigate the potential causality between top management's rationale of CI and how middle managers perceive and act upon the initiative, the Experimental Vignette Methodology (EVM) is used with participants from one of the largest banks in the Netherlands. The EVM is adopted because a vignette offers a hypothetical situation that resembles a real-life organizational setting, and thus avoids some of the disadvantages arising from other research methods such as surveys and case studies. In a traditional survey, the links between different aspects that influence opinion formation are not clear, so the research results become less valid (Alexander and Becker 1978; Schoenberg and Ravdal 2000). In EVM, a specific and as detailed as possible hypothetical scenario is sketched, which participants can go through (largely) unbiased. This will reduce the chance of socially desirable answers (Alexander and Becker 1978). The main added value of an EVM-based study is its explanatory power. In this respect, the participant does not give his/her opinion on isolated aspects but on an integrated description of the situation (Atzmüller and Stiener 2010; Jenkins et al. 2010).

More specifically, a vignette is "a short, carefully constructed description of a person, object or situation, representing a systematic combination of characteristics" (Atzmüller and Stiener 2010, p. 128). By using vignettes, in which a concrete and detailed hypothetical scenario is outlined, the participants can go through a decision making process in a realistic and unbiased manner. When the text of the vignette is compiled in such a way that the participant is included in the story, the questions to be asked are less personal and therefore less threatening (Barter and Renold 2000). This reduces the chance that participants give short-sighted and socially desirable answers (e.g. Barter and Renold 2000; Wilks 2004). Moreover, by exposing the participants to an environment that feels natural to them, EVM serves to resemble daily practice as closely as possible (Aguinis and Lawal 2013). 
Based on one of the authors' extensive professional experience at banks, a hypothetical scenario of a bank was prepared, called "The Piggy Bank. "As part of the experiment, all participants received the base case scenario in which they work as a manager at "The Piggy Bank", involving a vignette that contains a short description of the change program "GOLD", aimed at implementing CI in this bank.

The description of the exact aim of the "GOLD" program was slightly altered to create two situations: vignette 1 focused more on implementing $\mathrm{CI}$ as a management approach and vignette 2 on the implementation of $\mathrm{CI}$ as an efficiency program (see Figure 1).

\subsection{Sample}

To obtain participants for the experiment, one of the authors contacted program managers (involved in CI changes) and management team members of the various business lines within the bank to construct a list of the names and business e-mail addresses of all middle managers. This resulted in a total number of 474 potential participants. Each of these middle managers received an e-mail including a password-protected link to the online environment. The unique login information ensured confidentiality of both the vignette and the middle managers response. All participants were randomly assigned to one of the vignettes. The participating middle managers were asked to provide the following personal information: gender, age, business line, reporting line, level of education, years of experience at the bank, years of experience at current department, and years of experience with continuous improvement. Table 1 provides descriptive information on the sample of middle managers participating in this study. The sample of participants included 72 male $(67.3 \%)$ and 35 female $(32.7 \%)$ managers, ranging in age from 33 to $64(\mathrm{M}=47.3)$. On average, the participants had 3.4 years of experience in working with CI. In terms of work experience, 95 (88.8\%) participants had more than ten years of experience. In terms of the highest level of education obtained, 6 managers hold a postgraduate degree (5.6\%), 37 hold a master degree (34.6\%) and 58 have a bachelor degree (54.2\%).

Table 1: Sample

\subsection{Scenarios}

\begin{tabular}{|l|l|}
\hline Sample & Mean (frequency) \\
\hline $\mathrm{N}$ & 107 \\
\hline Male & $72(67.3 \%)$ \\
\hline Female & $35(32.7 \%)$ \\
\hline Mean age (in years) & 47.27 \\
\hline Experience (in years) & \\
\hline $0-2$ & $3(2.8 \%)$ \\
\hline $3-5$ & $2(1.8 \%)$ \\
\hline $6-10$ & $7(6.5 \%)$ \\
\hline$>10$ & $95(88.8 \%)$ \\
\hline Experience in department (in years) & \\
\hline $0-2$ & $47(43.9 \%)$ \\
\hline $3-5$ & $31(28.9 \%)$ \\
\hline $6-10$ & $20(18.7 \%)$ \\
\hline$>10$ & $9(8.4 \%)$ \\
\hline Mean experience with CI (in years) & 3.4 \\
\hline Highest degree & \\
\hline Postgraduate & $6(5.6 \%)$ \\
\hline Master & $37(34.6 \%)$ \\
\hline Bachelor & $58(54.2 \%)$ \\
\hline MBO & $2(1.9 \%)$ \\
\hline High school & $4(3.7 \%)$ \\
\hline
\end{tabular}

The information in the overall scenario was the same for each participant (see appendix 1). The vignettes were altered at different points regarding use of words and the sequence of the enumeration of goals to be achieved with the "GOLD" program. The two CI implementation strategies are extensively explained in the Introduction section, as the two archetypical top management strategies toward CI. The integral management approach is the strategy that is consistent with CI, but top management often ends up using CI as a quick fix for financial/efficiency problems, without a deliberate effort to create and maintain the conditions needed. Methodologically, a vignette experiment requires the development of two straightforward conditions that can be clearly distinguished from each other. As a result, we decided to create a black/white contrast between the two top management approaches to CI. 


\section{Figure 1: Used Vignettes}

\section{Vignette A}

Within the context of continuous improvement, there is special attention for the implementation of a mentality change throughout the organization. The top management of Piggy Bank considers the implementation of the GOLD program as an investment in the vitality and performance of the organization. Therefore, it aims to initiate a substantial culture shift. The top management expects that the cultural change will increase customer satisfaction, involve employees and increase the profitability of the organization in the long term.

\section{Vignette B}

Within the context of continuous improvement, there is special attention to efficiency improvement throughout the organization. During the implementation of the GOLD program, several resources and tools have been handed to the organization in order to achieve this. The top management of The Piggy Bank considers the implementation of the GOLD program as an investment that contributes to the optimization of departments and chains. Therefore, it aims to realize process improvements that will result in cost reductions. The top management expects that the efficiency improvement will increase customer satisfaction, involve employees and increase the profitability of the organization in the long term.

A comparison of the characteristics of middle managers over the two vignettes serves to check the random assignment of the middle managers to these vignettes. Table 2 shows the means, standard deviations and t-tests for the two groups. No statistically significant differences exist between the two groups that were assigned a different vignette, indicating that randomization has its desired effect. Furthermore, to ensure that the scenario and vignette would reflect a realistic situation, the research team pre-tested the experiment. This test included eight employees of the bank participating in the vignette study and four employees of other large banks where a similar CI program was introduced. Based on their feedback, both the scenarios and vignettes were further refined and some questions were altered to better ensure the anonymity of the participants. In addition, the term 'middle manager' was replaced with 'manager' since all participants are middle managers.

Table 2: Check of randomization

\begin{tabular}{|l|l|l|}
\hline Treatments & Integral & Cost Cutting \\
\hline $\mathrm{N}$ & 60 & 47 \\
\hline Gender & $1.65(0.48)$ & $1.70(0.46)$ \\
\hline $\mathrm{t}$-value & & 0.57 \\
\hline Age & $48.25(6.66)$ & $46(6.46)$ \\
\hline $\mathrm{t}$-value & & 0.08 \\
\hline Education & $4.37(0.78)$ & $4.36(0.79)$ \\
\hline t-value & & 0.97 \\
\hline Years at organization & $3.87(0.50)$ & $3.74(0.71)$ \\
\hline t-value & & 0.32 \\
\hline Years at department & $2.03(1.04)$ & $1.77(0.89)$ \\
\hline t-value & & 0.16 \\
\hline $\begin{array}{l}\text { Years } \\
\text { experience }\end{array}$ & $3.47(1.65)$ & $3.36(1.85$ \\
\hline $\mathrm{t}$-value & & \\
\hline Type of department & & 0.76 \\
\hline $\mathrm{t}$-value & $2.47(1.20)$ & $2.66(1.36)$ \\
\hline Function level & & 0.44 \\
\hline $\mathrm{t}$-value & $4.15(1.07)$ & $4.09(1.12)$ \\
\hline
\end{tabular}

\subsection{Measures}

The experiment includes seven questions (see Table 3) that aim to capture the outcome variables included in the set of hypotheses formulated in section 2. First drafts of these questions were discussed with several managers in the financial service industry, and adapted based on their feedback. When participants replied to the questions on the basis of the received vignette, they had to make a choice based on a 5-point Likert scale (totally disagree - disagree - agree nor disagree - agree or totally agree). 
Table 3: Outcome measures

\begin{tabular}{|l|l|}
\hline Outcome Measures & Questions \\
\hline $\begin{array}{l}\text { Permanent change } \\
\text { culture }\end{array}$ & $\begin{array}{l}\text { I consider GOLD to be a program that results in a permanent change in our } \\
\text { organizational culture. }\end{array}$ \\
\hline Integration CI culture & $\begin{array}{l}\text { I expect that GOLD results in the implementation and integration of continuous } \\
\text { improvement within our culture. }\end{array}$ \\
\hline Adaptation to new culture & $\begin{array}{l}\text { Because of GOLD, I will steer the department toward achieving continuous } \\
\text { improvement and the adaption to a new organizational culture. }\end{array}$ \\
\hline Fulfilling customer needs & Because of GOLD, I focus on fulfilling customer needs. \\
\hline $\begin{array}{l}\text { Steering on customer } \\
\text { satisfaction }\end{array}$ & Because of GOLD, I will steer the department toward customer satisfaction. \\
\hline \begin{tabular}{l} 
Work atmosphere \\
\hline
\end{tabular} & The work atmosphere will improve due to the implementation of GOLD. \\
\hline
\end{tabular}

\section{Results}

Table 4 reports the results of the vignette experiment. Consistent with several hypotheses, when CI is implemented as an integral management approach rather than an efficiency program, middle managers perceive CI to become more part of the organizational culture (H1) and they expect their company to become more focused on its customers (H2). Also, middle managers expect a significantly better work atmosphere (H3). The results of the statistical analysis of each hypothesis in Table 4 show that these effects are statistically significant (see P-values) and have a high F-value.

Table 4: Experimental results

\begin{tabular}{|c|c|c|c|}
\hline & Treatments & Integral & Cost Cutting \\
\hline & $\mathbf{N}$ & 60 & 47 \\
\hline \multirow{4}{*}{$\begin{array}{l}\text { Permanent } \\
\text { culture }\end{array}$} & Implementation type & 3.73 & 3.26 \\
\hline & SD & 0.88 & 1.17 \\
\hline & P-value* & 0.018 & \\
\hline & F-value & 5.755 & \\
\hline \multirow[t]{4}{*}{ Integration CI culture } & Implementation type & 3.68 & 3.13 \\
\hline & SD & 0.83 & 1.05 \\
\hline & P-value* & 0.004 & \\
\hline & F-value & 8.932 & \\
\hline \multirow{4}{*}{$\begin{array}{lll}\begin{array}{l}\text { Adaptation } \\
\text { culture }\end{array} & \text { to new } \\
\end{array}$} & Implementation type & 3.97 & 3.45 \\
\hline & SD & 0.82 & 0.99 \\
\hline & P-value* & 0.004 & \\
\hline & F-value & 8.707 & \\
\hline \multirow{4}{*}{$\begin{array}{ll}\begin{array}{l}\text { Fulfilling } \\
\text { needs }\end{array} & \text { customer } \\
\end{array}$} & Implementation type & 3.42 & 2.89 \\
\hline & SD & 0.90 & 1.10 \\
\hline & P-value* & 0.010 & \\
\hline & F-value & 6.981 & \\
\hline \multirow{4}{*}{$\begin{array}{l}\text { Steering on customer } \\
\text { satisfaction }\end{array}$} & Implementation type & 3.72 & 3.30 \\
\hline & SD & 0.90 & 1.08 \\
\hline & P-value* & 0.035 & \\
\hline & F-value & 4.589 & \\
\hline \multirow[t]{4}{*}{ Work atmosphere } & Implementation type & 3.50 & 3.02 \\
\hline & SD & 0.72 & 0.84 \\
\hline & P-value* & 0.003 & \\
\hline & F-value & 9.536 & \\
\hline
\end{tabular}

\section{Discussion and Conclusion}


This study explores whether the way top management conceptualizes the rationale of the CI program affects how middle managers respond in the context of getting CI adopted and implemented. In this respect, CI can be conceived as a state of the organization in which all its members contribute to performance improvement by continuously implementing small changes in their work processes (Jørgensen et al. 2003). The findings indeed show that implementing CI as an integral management approach rather than as an efficiency program leads to better integration in the organizational culture, a more customer-oriented focus and a better work atmosphere compared to implementing CI as a cost-cutting tool. This implies that a more integral approach helps to prevent that the organization ends up with 'just' another tool, with a rather short time horizon and without any substantial changes in behavior and culture toward CI (Dibia et al. 2014; Fryer and Ogden 2014; Mann 2009). These findings are discussed in more detail in the remainder of this section.

The main findings from this study demonstrate that, when CI is implemented as an integral management approach, middle managers believe $\mathrm{CI}$ is more likely to be integrated into the organizational culture. This is an important finding, because embedding CI in the organizational culture apparently contributes to the sustainability of CI in the organization (Mann 2005; O'Rouke 2005). This particular result of the vignette experiment is in line with previous findings (Bhasin 2012; Bhasin and Burcher 2006). From a practical perspective, it means that conceiving CI as an integral management approach by top management has a positive effect on middle management's expectation that CI can be incorporated into the organizational culture in a sustained manner. And precisely the element of sustainability is often a major problem (Bessant et al. 1994; Found and Harvey 2006; Pearce and Pons 2017). To survive in today's highly competitive market, a focus on customers is of great importance (Brettel et al. 2014; McFarlane 2013). Knowing what is happening and what customers' expectations are, ensures that one can adapt and connect to the ever-changing customer needs (Tomczak et al. 2018; Wiesner et al. 2015). The findings confirm that, if top management implements $\mathrm{CI}$ as an integral management approach, middle managers expect that the organization becomes more customerfocused. This is important because one of the risks of many CI programs is that they mainly focus on internal efficiency instead of customer satisfaction (Fryer et al. 2007; Huang and Rust 2014).

In order to serve customers well, a good working atmosphere in the organization appears to be very important (Stock et al. 2017; Varghese et al. 2017). Previous studies have observed a negative association between CI and work atmosphere, due to the risk of job loss, more monotonous work and increasing peer pressure (McCann et al. 2008; Sim et al. 2015). The results of our study lead to more nuanced insights. In particular, middle managers perceive less negative associations regarding the work atmosphere when $\mathrm{CI}$ is implemented as an integral management approach rather than a cost-cutting tool. Top management's focus during the implementation of CI should thus be on securing ample opportunities for employee participation, development and growth (Angelis et al. 2011).

As such, it is better to create an optimal level of service productivity (Huang and Rust 2014), which often involves a trade-off between customer focus on the one hand and efficiency on the other. If this is done in a proper way, optimizing the operations will not only improve efficiency but also the service level to external customers (Radnor and Johnston 2013). Eventually, optimizing the operations will not only improve customer service but also improve the financial performance of the organization (Duncan and Elliott 2002; Swank 2003). To further disentangle the complexity of CI change efforts, in-depth research needs to be done to establish how the interaction between top management and middle managers affects the implementation of CI. Here, the framework of Floyd and Wooldridge (1992; 1996), which combines upward and downward influence with behaviours that integrate and support strategies on one hand and diverge from official strategy on the other, can be very helpful.

\subsection{Limitations}

This study has a number of limitations. First, the randomized experiment in this study results in a stylized setting in which respondents are asked to make a choice based on limited information. One of the risks this entails is that respondents tend to judge situations or persons more rationally than they would normally do. Since the participants' judgements were simulated by hypothetical situations, one might question whether the results of such an exercise accurately model authentic behaviour. However, by using a traditional survey method, middle managers of the organization in question would very likely be giving socially desirable answers regarding the implementation of CI. In this respect, the vignette designed in this study provides a specific situation for the participants that comes as close as possible to authentic situations they experienced in the past. Second, although the results arising from this study are insightful, the research was performed within one organization which implies that the results may not be generalizable. Therefore, future work in this area needs to engage in replication and validation efforts regarding the results of this study in other financial service organizations as well as organizations in other industries. 


\subsection{Conclusion}

The main findings from this study suggest that top management's conceptualization of the rationale of a CI program significantly affects the role of middle management in getting CI implemented. Middle managers have an important role in the organization-wide implementation and adoption of CI. The results clearly demonstrate the effect of how top management conceptualizes CI on the ways in which middle managers perceive CI being adopted in the organizational culture, and expect an increased customer focus and improved work atmosphere. The effect on middle managers' fear for their own positions is not supported. A significant risk arising from CI initiatives is that most people in the organization perceive CI as another downsizing method focused on short-term financial targets, rather than the necessary deeper cultural change. The findings arising from this study suggest that middle managers can only help reduce this risk if top managers commit themselves to $\mathrm{CI}$ as an integrated management approach and communicate this in a consistent manner, time and again, throughout the entire organization.

\section{References}

Aarnio, T. (2015). The strengthened business process matrix - A novel approach for guided continuous improvement at service-oriented SMEs. Knowledge and Process Management, 22, 180-190.

Achanga, P., Shehab, E., Rajkumar, R. and Nelder, G. (2006). Critical success factors for lean implementation within SMEs. Journal of Manufacturing Technology Management, 17, 460-471.

Aguinis, H. and Lawal, S. (2013). eLancing: a review and research agenda for bridging the science-practice gap. Human Research Management, 23, 6-17.

Alexander, C.S. and Becker, H.J. (1978). The use of vignettes in survey research. Public Opinion Quarterly, 42, 93104.

Aloini, D., Martini, A. and Pellegrini, L. (2011). A structural equation model for continuous improvement: A test for capabilities, tools and performance. Production Planning \& Control, 22, 628-648.

AL-Najem, M., Dhakal, H. and Bennett, N. (2012). The role of culture and leadership in lean transformation: A review and assessment model. International Journal of Lean Thinking, 3, 119-138.

Anderson, E.W., Fornell, C. and Rust, R.T. (1997). Customer satisfaction, productivity and profitability: Differences between goods and services. Marketing Science, 16, 129-145.

Andrés-López, E., González-Requena, I. and Sanz-Lobera, A. (2015). Lean service: reassessment of lean manufacturing for service activities. Procedia Engineering, 132, 23-30.

Angelis, J., Conti, R., Cooper, C. and Gill, C. (2011). Building a high-commitment lean culture. Journal of Manufacturing Technology Management, 22, 569-586.

Argyris, C. (2004). Reasons and Rationalizations: The Limits to Organizational Knowledge. Oxford: Oxford University Press.

Atzmüller, C. and Steiner, P.M. (2010). Experimental vignette studies in survey research. Methodology. European Journal of Research Methods for the Behavioral and Social Sciences, 6, 128-138.

Azuan, S. and Ahmad, S. (2013). Culture and Lean manufacturing: Towards a holistic framework. Australian Journal of Basic and Applied Sciences, 7, 334-338.

Balding, C. (2005). Embedding organisational quality improvement through middle manager ownership. International Journal of Health Care Quality Assurance, 18, 271-288.

Banerjee, R. N. and Mio, H. (2017). The impact of liquidity regulation on banks. Journal of Financial Intermediation, 35, Part B, 30-44.

Barter, C. and Renold, E. (2000). 'I wanna tell you a story': Exploring the application of vignettes in qualitative research with children and young people. International Journal of Social Research Methodology, 3, 307-323.

Basu, P. and Ahmed, P. (2012). The employee perspective in lean environment. Drishtikon: A Management Journal, 3, $1-25$.

Basu, P., Chowdhury, S. and Alam, P.A. (2015). A model-based approach of flexibility and its impact on organization and employee welfare in lean environment. Decision, 42, 269-277.

Bessant, J., Caffyn, S., Gilbert, J., Harding, R. and Webb, S. (1994). Rediscovering continuous improvement. Technovation, 14, 17-29.

Bessant, J., Caffyn, S. and Gallagher, M. (2001) An evolutionary model of continuous improvement behavior. Technovation, 21, 67-77.

Bhamu, J. and Singh Sangwan, K. (2014). Lean manufacturing: literature review and research issues. International Journal of Operations \& Production Management, 34, 876-940.

Bhasin, S. (2011). Performance of organisations treating lean as an ideology. Business Process Management Journal, 17, 986-1011. 
Bhasin, S. (2012). Prominent obstacles to lean. International Journal of Productivity and Performance Management, 61, 403-425.

Bhasin, S. and Burcher, P. (2006). Lean viewed as a philosophy. Journal of Manufacturing Technology Management, 17, 56-72.

Bhuiyan, N., Baghel, A. and Wilson, J. (2006). A sustainable continuous improvement methodology at an aerospace company. International Journal of Productivity and Performance Management, 55, 671-687.

Bicheno, J. (2008). The lean toolbox for service systems. Picsie books, Buckingham.

Bodine, K. (2011). Focus on your customer's customer. HBR.org digital article, available at:https://hbr.org/2011/04/why-you-should-focus-on-yo

Boyle, T., Scherrer-Rathje, M. and Stuart, I. (2011). Learning to be lean: The influence of external information sources in lean improvements. Journal of Manufacturing Technology Management, 22, 587-603.

Brettel, M., Friederichsen, N., Keller, M. and Rosenberg, M. (2014). How virtualization, decentralization and network building change the manufacturing landscape: An industry 4.0 perspective. International Journal of Science, Engineering and Technology, 8, 37-44.

Buick, F., Blackman, D. and Johnson, S. (2018). Enabling middle managers as change agents: Why organisational support needs to change. Australian Journal of Public Administration, 77, 222-235.

By, R.T. (2005). Organisational change management: A critical review. Journal of Change Management, 5, 369-380.

Carlborg, P., Kindström, D. and Kowalkowski, C. (2013). A lean approach to service productivity improvements: Synergy or oxymoron? Managing Service Quality, 23, 291-304.

Cascio, W. (1993). Downsizing: What do we know? What have we learned? Academy of Management Executive, 7, 95104.

Caughron, J. and Mumford, M. (2011). Embedded leadership: How do a leader's superiors impact middle-management performance? The Leadership Quarterly, 23, 342-353.

Chen, H., Lindeke, R. and Wyrick, D. (2010). Lean automated manufacturing: avoiding the pitfalls to embrace the opportunities. Assembly Automation, 30, 117-123.

Collis, D. (2016) Lean strategy. Harvard Business Review, 94(2), 63-68.

Cudney, E. and Elrod, C. (2011). A comparative analysis of integrating lean concepts into supply chain management in manufacturing and service industries. International Journal of Lean Six Sigma, 2, 5-22.

Dahlgaard, J. and Dahlgaard-Park, S. (2006). Lean production, six sigma quality, TQM and company culture. The TQM Magazine, 18, 263-281.

Davis, D. and Fisher, T. (2002). Attitudes of middle managers to quality-based organisational change. Managing Service Quality, 12, 405-413.

Delizonna, L. (2017). High-performing teams need psychological safety. Here's how to create it.HBR.org digital article, available at: https://hbr.org/2017/08/high-performing-teams-need-psychological-safety-heres-how-tocreate-it

Denham, N., Ackers, P. and Travers, C.T. (1997). Doing yourself out of a job? How middle managers cope with empowerment. Employee Relations, 19, 147-159.

Dibia, K.I., Nath Dhakal, H. and Onuh, S. (2014). Lean "leadership people process outcome"(LPPO) implementation model. Journal of Manufacturing Technology Management, 25, 694-711.

Duncan, E. and Elliott, G. (2002). Customer service quality and financial performance among Australian retail financial institutions. Journal of Financial Services Marketing, 7, 25-41.

Duncan, E. and Elliott, G. (2004). Efficiency, customer service and financial performance among Australian financial institutions. The International Journal of Bank Marketing, 22, 319-341.

Engle, R.L., Lopez, E.R., Gormley, K.E., Chan, J.A., Charns, M.P., and Lukas, C.V. (2017). What roles do middle managers play in implementation of innovative practices? Health care management review, 42, 14-27.

Fine, D., Hansen, M. and Roggenhofer, S. (2008). From lean to lasting: Making operational improvements stick. The McKinsey Quarterly, 108-118.

Floyd, S.W. and Lane, P.J. (2000). Strategizing throughout the organization: Managing role conflict in strategic renewal. Academy of Management Review, 25, 154-177.

Floyd, S.W. and Wooldridge, B. (1992). Middle management involvement in strategy and its association with strategic type: A research note. Strategic Management Journal, 13, S1, special issue "Strategy Process: Managing Corporate Self-Renewal", 153-167.

Floyd, S.W. and Wooldridge, B. (1996). The strategic middle manager: How to create and sustain competitive advantage. Jossey-Bass, San Francisco.

Found, P.A. and Harvey, R. (2006). The role of leaders in the initiation and implementation of manufacturing process change. International Journal of Knowledge \& Change Management, 6, 35-46. 
Fryer, K.J. and Ogden, S. (2014). Modelling continuous improvement maturity in the public sector: key stages and indicators. Total Quality Management \& Business Excellence, 25, 1039-1053.

Fryer, K.J., Jiju A. and Douglas, A. (2007). Critical success factors of continuous improvement in the public sector: A literature review and some key findings. The TQM Magazine, 19, 497-517.

Glover, W.J., Farris, J.A. and Van Aken, E.M. (2015). The relationship between continuous improvement and rapid improvement sustainability. International Journal of Production Research, 53, 4068-4086.

Gurumurthy, A. and Kodali, R. (2011). Design of lean manufacturing systems using value stream mapping with simulation. Journal of Manufacturing Technology Management, 22, 444-473.

Gulati, R. and Oldroyd, J.B. (2005). The quest for customer focus. Harvard Business Review, 83, 92-101.

Hancock, D. and Dewatripont, M. (2018). Banking and regulation: The next frontier. Journal of Financial Intermediation, 35, 1-2.

Harrington, D. and Williams, B. (2004). Moving the quality effort forward - the emerging role of the middle manager. Managing Service Quality, 4, 297-306.

Heine, I., Schmitt, R. and Beaujean, P. (2016). Critical incidents of quality orientation in lower and middle management. The TQM Journal, 28, 734-744.

Hellsten, U. and Klefsjö, B. (2000). TQM as a management system consisting of values, techniques and tools. The TQM magazine, 12, 238-244.

Hines, P and Butterworth, C. (2019). The Essence of Excellence. Creating a Culture of Continuous Improvement. S A Partners, Caerphilly.

Hines, P., Found, P., Griffiths, G. and Harrison, R. (2011). Staying Lean: Thriving, Not Just Surviving. Second Edition, Productivity Press, New York.

Hines, P., Taylor, D. and Walsh, A. (2018). The Lean journey: have we got it wrong? Total Quality Management \& Business Excellence, forthcoming. DOI: 10.1080/14783363.2018.1429258

Holden, L. and Roberts, I. (2004). The depowerment of European middle managers: Challenges and uncertainties. Journal of Managerial Psychology, 19,269-287.

Holmemo, M.D.-Q. and J.A. Ingvaldsen (2016). Bypassing the dinosaurs? How middle managers become the missing link in lean implementation. Total Quality Management \& Business Excellence, 27, 1332-1345.

Hirzel, A.K., Leyer, M. and Moormann, J. (2017). The role of employee empowerment in the implementation of continuous improvement: Evidence from a case study of a financial services provider. International Journal of Operations \& Production Management, 37, 1563-1579.

Huang, M.H. and Rust, R. (2014). Should your business be less productive? MIT Sloan Management Review, 55, 6772.

Huy, Q. (2011). How middle managers' group-focus emotions and social identities influence strategy implementation. Strategic Management Journal, 32, 1387-1410.

Jayaram, J., Vickery, S., and Droge, C. (2008). Relationship building, lean strategy and firm performance: an exploratory study in the automotive supplier industry. International Journal of Production Research, 46, 56335649.

Jenkins, N., Bloor, M., Fischer, J., Berney, L. and Naele, J. (2010). Putting it in context: The use of vignettes in qualitative interviewing. Qualitative Research, 10,175-198.

Jørgensen, F., Boer, H. and Gertsen, F. (2003). Jump-starting continuous improvement through self-assessment. International Journal of Operations \& Production Management, 23, 1260-1278.

Kaye, M. and Anderson, R. (1999). Continuous improvement: The ten essential criteria. The International Journal of Quality \& Reliability Management, 16, 485-506.

Lacksonen, T., Rathinam, B., Pakdil, F. and Gülel, D. (2010). Cultural issues in implementing lean production. Proceedings of Industrial Engineering Research Conference 2010.

Lam, M., O'Donnell, M. and Robertson, D. (2015). Achieving employee commitment for continuous improvement initiatives. International Journal of Operations \& Production Management, 35, 201-205.

Lasrado, F. (2018). Achieving Organizational Excellence: A Quality Management Program for Culturally Diverse Organizations. Springer, Berlin.

Madhani, P. M. (2017). Customer-focused supply chain strategy: developing business value-added framework. The IUP Journal of Supply Chain Management, 14, 7-22.

Mann, D. (2005). Creating a lean culture: Tools to sustain lean conversions. Productivity Press, New York.

Mann, D. (2009) The missing link: Lean leadership. Frontiers of Health Services Management, 26, 15-26.

McCann, L., Hassard, J., Granter, E. and Hyde, P. (2015). Casting the lean spell: The promotion, dilution and erosion of lean management in the NHS. Human relations, 68, 1557-1577. 
McCann, L., Morris, J. and Hassard, J. (2008). Normalized intensity: The new labour process of middle management. Journal of Management Studies, 45, 343-371.

McFarlane, D.A. (2013). The strategic importance of customer value. Atlantic Marketing Journal, 2, 62-75.

McGinn, D. (2011). Welcome to creating a customer-centered organisation. HBR.org digital article, available at: https://hbr.org/2011/04/welcome-to-creating-a-customer

McLean, R., Antony, J. and Dahlgaard, J. (2017). Failure of continuous improvement initiatives in manufacturing environments: a systematic review of the evidence. Total Quality Management \& Business Excellence, 28, 219-237.

McQuade, D. (2008). New development: leading lean action to transform housing services. Public Money and Management, 28, 57-60.

Nelson, S. and Yeo, R. (2012). Action learning for middle management development: The case of an Australian statebased large organization. International Journal Human Resources Development and Management, 12, 292307.

Netland, T.H. (2016). Critical success factors for implementing lean production: the effect of contingencies. International Journal of Production Research, 54, 2433-2448.

Oakland, J. and Tanner, S. (2007). A new framework for managing change. The TQM Magazine, 19, 572-589.

O'Rourke, P. (2005). A multiple-case comparison of Lean six sigma deployment and implementation strategies. ASQ World Conference on Quality and Improvement proceedings, 59, 581-591.

Parasuraman, A. (2002). Service quality and productivity: a synergistic perspective. Managing Service Quality, 12, 6-9.

Parasuraman, A., Berry, L. and Zeithaml, V. (1991). Understanding Customer Expectations of Service. MIT Sloan Management Review, 32, 39-48.

Pearce, A. and Pons, D.J. (2017). Defining Lean Change-Framing Lean Implementation in Organizational Development. International Journal of Business and Management, 12, 10-22.

Poksinska, B., Swartling, D. and Drotz, E. (2013). The daily work of Lean leaders-lessons from manufacturing and healthcare. Total Quality Management \& Business Excellence, 24, 886-898.

Psychogios, A., Wilkinson, A. and Szamosi, L. (2009). Getting to the heart of the debate: TQM and middle manager autonomy. Total Quality Management \& Business Excellence, 20, 445-466.

Radnor, Z. and Johnston, R. (2013). Lean in UK Government: internal efficiency or customer service. Production Planning and Control, 24, 903-915.

Rahman, S., Laosirihongthong, T. and Sohal, A. S. (2010). Impact of lean strategy on operational performance: a study of Thai manufacturing companies. Journal of Manufacturing Technology Management, 21, 839-852.

Ramakrishnan, S., Testani, M. and Orth, R. (2009, October). Critical Factors for Sustainable Kaizen Events-People, Process and Technology. In Proceedings of the 2009 American Society for Engineering Management Conference, Springfield, $M O$ (pp. 1-6).

Rentes, A., Araujo, C. and Rentes, V. (2009). Best practice examples in sustaining improvements from lean implementation. Industrial Engineering Research Conference 2010.

Rother, M. (2010). Toyota kata. MacGraw Hill, New York.

Schoenberg N. and Ravdal H. (2000). Using vignettes in awareness and attitudinal research. International Journal of Social Research Methodology, 3, 63-74.

Shafiq, M., Lasrado, F. and Hafeez, K. (2019). The effect of TQM on organisational performance: Empirical evidence from the textile sector of a developing country using SEM. Total Quality Management \& Business Excellence, 30, 31-52.

Sim, K.L. and Rogers, J. (2009). Implementing lean production systems: Barriers to change. Management Research News, 32, 37-49.

Sim, K.L., Curatola, A.P. and Banerjee, A. (2015). Lean Production Systems and Workers Satisfaction: A Field Study. Advances in Business Research, 6, 79-100.

Snee, R. (2010). Lean Six Sigma - getting better all the time. International Journal of Lean Six Sigma, 1, 9-29.

Song, L., Zhang, X. and Wu, J. (2014). A multilevel analysis of middle manager performance: the role of CEO and top management leadership. Management and Organization Review, 10, 275-297.

Stock, R.M., de Jong, A. and Zacharias, N.A. (2017). Frontline Employees' Innovative Service Behavior as Key to Customer Loyalty: Insights into FLEs' Resource Gain Spiral*. Journal of Product Innovation Management, $34,223-245$.

Stoker, J. (2006). Leading middle management: Consequences of organizational changes for tasks and behaviors of middle managers. Journal of General Management, 32, 31-42.

Swank, C. (2003). The lean service machine. Harvard Business Review, 81, 123-123. 
Tippman, E., Scott, P. and Mangematin, V. (2013). Stimulating knowledge search routines and architecture competences: The role of organizational context and middle management. Lang Range Planning, 47, 206-223.

Tomczak, T., Reinecke, S. and Kuss, A. (2018). Strategic Marketing: Market-Oriented Corporate and Business Unit Planning. Gabler Verlag, Wiesbaden.

Vandermerwe, S. (2004). Achieving deep customer focus. MIT Sloan Management Review, 45, 26-34.

Vänje, A. and Brännmark, M. (2017). Walking around the pyramids: Managers' shop-floor activities in Lean-inspired organizations. Economic and Industrial Democracy, 38, 495-512.

Van Assen, M.F. (2018). The moderating effect of management behavior for Lean and process improvement. Operations Management Research, 11, 1-13.

Van Dun, D.H. and Wilderom, C.P.M. (2016). Lean teams, In: Netland, T.H., Powell, D.J. (Eds), The Routledge Companion to Lean Management. Routledge, New York, NY, pp. 106-117.

Van Maanen, J. and Barley, S.R. (1984). Occupational communities: Culture and control in organizations. Research in Organizational Behavior, 6, 287-365.

Varghese, J., Edward, M. and George, B. (2017). Organizational factors that influence salespersons' attitude towards customer service in the financial service industry: Opportunities to generate innovation. Palermo Business Review, 15, 65-78.

Wiesner, S., Freitag, M., Westphal, I. and Thoben K.D. (2015). Interactions between service and product lifecycle management. In: 7th CIRP IPSS Conference, Saint Etienne (France), pp.36-41.

Wilks, T. (2004). The use of vignettes in qualitative research into social work values. Qualitative Social Work, 3, 7887.

Womack, J. and Jones, D.T. (2005). Lean solutions: How companies and customers can create value and wealth together. Free Press, New York.

Zarbo, R. (2012). Creating and sustaining a Lean culture of continuous process improvement. American Journal of Clinical Pathology, 138, 321-326.

\section{Appendix: Vignette questionnaire}

\section{Background}

The continuous improvement of operational processes is an enormous challenge for many organizations. Managers play an important role in this matter. The creation of a sustainable continuous improvement practice demands the development of a new way of working (this means: "the continuous improvement of operational processes") and its integration within the daily routines throughout the organization. In order to achieve this, involved managers experience pressure. Since you are a manager that participated in the Customer Excellence programme of XXXXX, you are approached to participate in this study.

\section{Our request?}

Please read the questions below carefully and subsequently answer them. The main objective of the first questions is to establish a general impression of your role as a manager. If you have any questions, please do not hesitate to contact (XXXXX). Your contribution to this research is highly appreciated.

\section{Propositions}

Please answer the questions below within the context of the above stated information. Execute this by answering each question with totally disagree, disagree, not disagree/ not agree, agree or totally agree.

\section{1)I consider GOLD as an implementation of the continuous improvement philosophy.}
$\square$ totally disagree $\quad \square$ disagree
$\square$ not
disagree/not $\square$ agree
$\square$ totally agree

2)I consider GOLD as a programme that results in a permanent shift of our organisational culture.
totally disagree
$\square$ disagree
$\square$ not
agree
disagree/not $\square$ agree
$\square$ totally agree 
3) I consider GOLD as an implementation of cost-cutting tools from a "lean" toolbox.

$\square$ totally disagree $\square$ disagree $\quad \begin{aligned} & \square \text { not disagree/not } \square \text { agree } \\ & \text { agree }\end{aligned}$

4)I consider GOLD as an effort to increase the efficiency of the organisation.

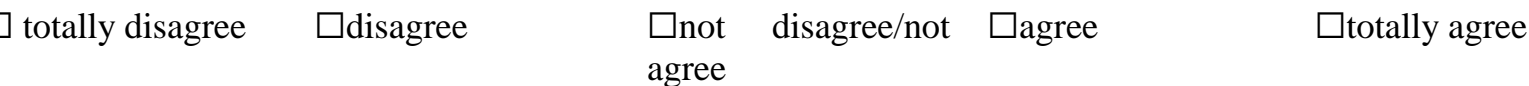

5)I expect that the top management allows me sufficient time to transfer GOLD into a concrete action plan for my department and to realise the objectives of GOLD.

$\square$ totally disagree $\square$ disagree $\quad \begin{aligned} & \square \text { not disagree/not } \square \text { agree } \\ & \text { agree }\end{aligned}$

6)I consider GOLD as a threat to my function.

$\square$ totally disagree $\square$ disagree $\quad \begin{aligned} & \square \text { not disagree/not } \square \text { agree } \\ & \text { agree }\end{aligned} \quad \square$ totally agree

7)I expect sufficient support from the top management for the implementation of change (GOLD).

$\square$ totally disagree $\square$ disagree $\quad \begin{aligned} & \square \text { not disagree/not } \quad \square \text { agree } \\ & \text { agree }\end{aligned} \quad \square$ totally agree

8)I expect that GOLD will lead to resistance within the organization.
totally disagree $\quad \square$ disagree
$\square$ not disagree/not $\square$ agree
agree
$\square$ totally agree

9)GOLD results in the implementation of continuous improvement within our culture.
totally disagre
$\square$ disagree
$\square$ not
agree
disagree/not $\square$ agree
$\square$ totally agree

10) GOLD results in a drastic cost decrease.

$\square$ totally disagree $\square$ disagree $\square$ not disagree/not $\square$ agree $\quad \square$ totally agree

11) The working atmosphere will improve due to the implementation of GOLD.

$\square$ totally disagree $\square$ disagree $\quad \square$ not disagree/not $\square$ agree $\square$ totally agree

12) I will support the top management by the implementation of the change (GOLD).

totally disagree $\square$ disagree $\quad \begin{gathered}\square \text { not } \\ \text { agree }\end{gathered}$ disagree/not $\square$ agree $\quad \square$ totally agree

13) I will fulfil a pioneering role in making GOLD a success.

$\square$ totally disagree $\quad \square$ disagree $\quad \square$ not disagree/not $\square$ agree $\quad \square$ totally agree agree

14) I perceive my role as crucial within the GOLD programme.

$\square$ totally disagree $\quad \square$ disagree $\quad \square$ not disagree/not $\square$ agree $\quad \square$ totally agree

15) Because of GOLD, I focus on fulfilling customer needs.

$\square$ totally disagree $\square$ disagree $\quad \square$ not $\quad$ disagree/not $\square$ agree $\quad \square$ totally agree agree 
16) I will investigate how GOLD can contribute to customer satisfaction.

$\square$ totally disagree $\square$ disagree $\quad \begin{aligned} & \square \text { not } \\ & \text { agree }\end{aligned} \quad$ disagree/not $\square$ agree $\quad \square$ totally agree

17) I will integrate GOLD and adapt it to the current way of working within my department(s)

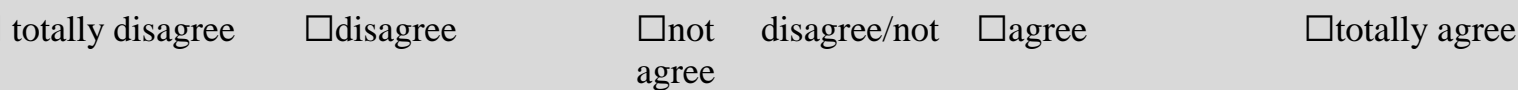

18) In the context of GOLD, I will adapt the organisation in order to meet customer needs in the best possible way.
totally disagree
$\square$ disagree
$\square$ not disagree/not $\square$ agree
agree
$\square$ totally agree

19) Because of GOLD, I focus on fulfilling customer needs at the lowest possible costs and shortest lead time.

$\square$ totally disagree $\square$ disagree $\quad \square$ not disagree/not $\square$ agree $\quad \square$ totally agree

20) I select the proper tools to achieve and monitor the GOLD objectives.

$\square$ totally disagree $\square$ disagree $\quad \begin{aligned} & \square \text { not } \\ & \text { agree }\end{aligned} \quad$ disagree/not $\square$ agree $\quad \square$ totally agree

21) I will determine specific KPI's to timely realise the efficiency objectives of GOLD.

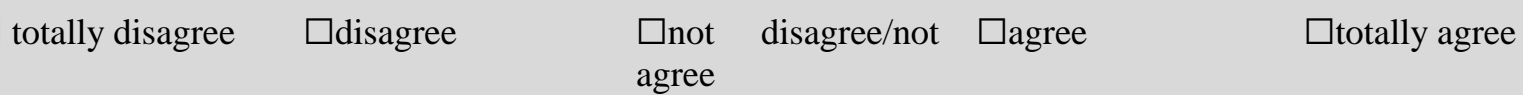

22) In the context of GOLD, I actively monitor individual and team KPI's in order to identify improvement possibilities.

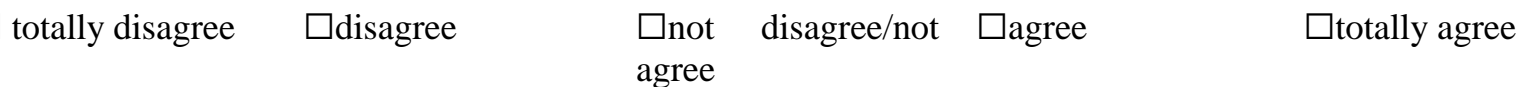

23) By implementing GOLD, I will solely focus on activities that are beneficial for me.
totally disagree
$\square$ disagree
$\square$ not disagree/not $\square$ agree
$\square$ totally agree

24) Because of GOLD, I will steer the department on efficiency.

totally disagree $\square$ disagree $\quad \begin{gathered}\square \text { not } \\ \text { agree }\end{gathered} \quad$ disagree/not $\square$ agree $\quad \square$ totally agree

25) Because of GOLD, I will steer the department on customer satisfaction.

totally disagree $\quad \square$ disagree $\quad \square$ not disagree/not $\square$ agree $\quad \square$ totally agree agree

26) Because of GOLD, I will steer the department on achieving continuous improvement and the adaption to a new organisational culture.

$\square$ totally disagree $\square$ disagree $\quad \begin{aligned} & \square \text { not } \\ & \text { agree }\end{aligned} \quad$ disagree/not $\square$ agree $\quad \square$ totally agree 


\section{General questions}

\begin{tabular}{|l|l|}
\hline Gender & \\
\hline Age & \\
\hline Function & \\
\hline Education level & $\square$ Elementary school \\
& $\square$ High school \\
& $\square$ MBO \\
& $\square$ HBO \\
& $\square$ University \\
& $\square$ Post doctoral education \\
\hline \multicolumn{1}{c|}{ Amount of years } & $\square 0-3$ years \\
working at ABN AMRO & $\square 3-5$ years \\
& $\square 6-10$ years \\
& $\square$ more than 10 years \\
\hline $\begin{array}{l}\text { Amount of years at } \\
\text { current department }\end{array}$ & $\square 0-3$ years \\
& $\square 3-5$ years \\
& $\square 6-10$ years \\
\hline $\begin{array}{l}\text { Years of experience with } \\
\text { CE/CI }\end{array}$ & $\square$ more than 10 years \\
\hline
\end{tabular}

\section{Open question}

Do you believe that you the organisation will still work according to Customer Excellence within 5 years? Why yes/no? 